\title{
MODELO SOCIOAMBIENTAL GLOBAL E MINERAÇÃO NO BRASIL: A RELAÇÃO ENTRE ESTADO E MERCADO EM DISCURSO
}

\section{Global socioenvironmental model and mining in Brazil: the relationship between State and market in discourse}

\author{
Paulo Everton M. Simões \\ Universidade Federal de Alagoas, Maceió, AL, Brasil \\ Sóstenes Ericson \\ Universidade Federal de Alagoas, Maceió, AL, Brasil
}

\section{Informações do artigo \\ Recebido em 03/12/2019 \\ Aceito em 07/06/2021}

doi>: https://doi.org/10.25247/2447-861X.2021.n252.p134-165

Esta obra está licenciada com uma Licença Creative Commons Atribuição 4.0 Internacional.

\section{Como ser citado (modelo ABNT)}

SIMÕES, Paulo Everton M.; ERICSON, Sóstenes. Modelo socioambiental global e mineração no Brasil: a relação entre Estado e mercado em discurso. Cadernos do CEAS: Revista Crítica de Humanidades. Salvador/Recife, v. 46, n. 252, p. 134-165, jan./abr. 2021. DOI: https://doi.org/10.25247/2447-861X.2021.n252.p134-165

\begin{abstract}
Resumo
O artigo examina os efeitos da relação entre Estado brasileiro e o mercado da mineração tendo em vista o desenvolvimento sustentável como modelo socioambiental vigente no capitalismo. Parte do pressuposto de que o relatório Brundtland forjou um modelo socioambiental, cujo objetivo central é remover a contradição entre crescimento econômico e preservação da Natureza. Utiliza-se o aporte teórico e metodológico da Análise do Discurso pecheuxtiana, cujos procedimentos teórico-analíticos são definidos à luz do materialismo histórico. No modelo socioambiental vigente, as grandes corporações, como é o caso da Vale, realizam uma apropriação privada dos bens naturais coletivos, pois necessitam aumentar sua produtividade e alcançam esse fim ao transformar bens não mercantis em mercadoria, ao mesmo tempo em que transferem os danos socioambientais à sociedade. A parceria entre Estado e mercado, no atual modelo socioambiental vigente, faz com que o poder do Estado conduza a tal apropriação, por parte da grande corporação transnacional de mineração, dos bens naturais coletivos, ao mesmo tempo em que transferem os danos socioambientais, decorrentes da atividade produtiva, à sociedade.
\end{abstract}

Palavras-Chave: Desenvolvimento Sustentável. Sustentabilidade. Estado. Vale.

\section{Abstract}

The article examines the effects of the relationship between the Brazilian State and the mining with a view to sustainable development as a prevailing social and environmental model in capitalism. It assumes that the Brundtland report has forget a socio-environmental model whose central objective is to remove the contradiction between economic growth and nature conservation. The theoretical and methodological support of the pecheuxtian Discourse Analysis is used, whose theoreticalanalytical procedures are defined in the light of historical materialism. In the prevailing socioenvironmental model, large corporations, such as Vale, carry out a private appropriations of collective natural goods, as they need to increase their productivity and achieve this end by transforming non-market goods into commodities, as the same time as they transfer their assets environmental damage to society. The partnership between State and market, in the current socio-environment model, makes the State power lead to such appropriation, by the large transnational mining corporation, of collective natural goods while transferring the social and environmental damage resulting from the productive activity, to society.

Keywords: Sustainable Development. Sustainability. State. Vale. 


\section{Introdução}

Este artigo expõe a relação de parceria entre o Estado brasileiro e o mercado da mineração, analisando a atuação da Vale a partir da sua privatização até os recentes crimes socioambientais por ela protagonizados em Mariana e Brumadinho, no estado de Minas Gerais. O aporte teórico e metodológico advém da Análise do Discurso Pêcheuxtiana, cujos procedimentos teórico-analíticos são definidos à luz do materialismo histórico. O objetivo do trabalho é analisar os efeitos da relação entre Estado brasileiro e o mercado da mineração, tendo em vista o desenvolvimento sustentável como modelo socioambiental vigente no capitalismo.

Inicialmente, são apresentadas as discussões teóricas fundamentais para definir o modelo socioambiental vigente, apresentando as suas origens para, então, revelar como tal modelo se tornou global e funcional ao capitalismo neoliberal. Demonstra-se que o desenvolvimento sustentável é um modelo socioambiental oriundo do ideário desenvolvimentista no capitalismo que, posteriormente, se transfigura em sustentabilidade, convertendo-se em uma perspectiva gerencialista do desenvolvimento sustentável vigente no mercado. Em seguida, são explicitados os procedimentos metodológicos e as reflexões, a partir da análise da sequência discursiva de referência. $O$ artigo finaliza destacando que a parceria entre Estado e mercado, no atual modelo socioambiental vigente, faz com que o poder do Estado conduza a uma apropriação, por parte da grande corporação transnacional de mineração, dos bens naturais coletivos, ao mesmo tempo em que há transferência dos danos socioambientais, decorrentes da atividade produtiva, à sociedade.

\section{As primícias do modelo socioambiental vigente}

Os primórdios do atual modelo socioambiental estão na fundação do subdesenvolvimento, a partir do final da década de 1940, quando aos países da periferia do capitalismo se impunha uma lógica de estímulo ao desenvolvimento, sinônimo de progresso material, um "dispositivo ideológico", por meio do qual, potências capitalistas se tornaram o modelo de desenvolvimento a ser alcançado pelas demais nações (MORAES, 2006). Em 1945, os Estados Unidos da América (EUA) se destacavam pela preeminência militar e econômica, pelo movimento de expandir o mercado para seus produtos e encontrar locais para investir seus excedentes de capital (ESCOBAR, 2007, p. 67).

Nesse contexto, o presidente estadunidense, Harry Truman, convocou os países pobres a seguirem a trajetória dos EUA e demais nações ricas, oferecendo-lhes conhecimento científico e tecnológico para livrá-los do atraso, da pobreza e da ignorância (SANTOS FILHO, 2005). O pronunciamento de posse é o acontecimento histórico que possibilitou aquilo que Escobar (2007) e Rist (2002) chamam de invenção do desenvolvimento. Nesse sentido, um enunciado funda o 
desenvolvimento, concomitantemente com a criação do seu oposto, o subdesenvolvimento: "we must embark on a bold new program for making the benefits of our scientific advances and industrial progress available for the improvement and growth of underdeveloped areas." (TRUMAN, 1949, grifo nosso) $)^{1}$.

Tal enunciado ressignifica a noção de desenvolvimento, fundando um sentido novo: o do subdesenvolvimento. Os EUA se impuseram como nação desenvolvida, capaz de tornar disponíveis os benefícios de seus avanços científicos e do seu progresso industrial às áreas subdesenvolvidas do mundo. Ao tempo em que se autodenominavam um país avançado, do ponto de vista científico e industrial, também instauraram, por meio da designação underdeveloped areas, o subdesenvolvimento de diversos países. Ao designar os países pobres, receptores de sua ajuda, como áreas subdesenvolvidas, necessitadas de desenvolvimento, fundou-se sentido, estabelecendo um novo sítio de significância (ORLANDI, 1993a).

O período imediatamente após a Segunda Guerra Mundial inaugura a fase desenvolvimentista da história recente, na qual o desenvolvimento era sinônimo de industrialização, modernização tecnológica e crescimento do Produto Interno Bruto. O interesse estadunidense e de outras potências voltou-se à periferia, em especial à América Latina ( $A L)$, sob a justificativa de oferecer apoio para o seu desenvolvimento, fazendo-a alcançar relevância no contexto político e econômico por dois motivos principais: primeiro, tornou-se um grande mercado para o capital dos países desenvolvidos; e, segundo, porque representava um território propenso a aderir ao comunismo (MORAES, 2006; ESCOBAR, 2007). A ameaça comunista é tratada por Harvey (2006) como um recurso ideológico, tanto para impossibilitar o surgimento de algum agrupamento rival dentro do mundo capitalista, bem como para favorecer a internacionalização do capital, principalmente dos EUA.

Para Moraes (2006), a política externa estadunidense atuava para oferecer um exemplo de nação e a intervenção para que o exemplo fosse seguido. O autor aponta o desenvolvimentismo como mecanismo ideológico que auxiliou a estruturar, social e politicamente, as nações jovens e também aquelas que estavam a se reconstruir, forjando a "imagem-destino", uma novidade, o país desenvolvido, como uma projeção a ser alcançada pelo Terceiro Mundo. Os EUA, portanto, se apresentavam como o "[...] mais bem acabado dos caminhos para a mais moderna das sociedades modernas [...]" (MORAES, 2006, p. 46).

\footnotetext{
1 "[...] devemos embarcar em um novo programa ousado para disponibilizar os benefícios de nossos avanços científicos e progresso industrial para a melhoria e o crescimento de áreas subdesenvolvidas." (TRUMAN, 1949, tradução nossa).
} 
A invenção do subdesenvolvimento e a criação de uma política da pobreza são consequências do desenvolvimento capitalista. Tornou-se urgente desenvolver o chamado "Terceiro Mundo", sob o argumento de que, para dar cabo da pobreza, característica comum a todos os países, seria preciso o crescimento econômico, resultado do desenvolvimento, convertido em verdade universal evidente e necessária (ESCOBAR, 2007). Harvey (2006) considera a invenção do subdesenvolvimento necessária à produção e circulação capitalista, que se dirigiu a estes países com vistas a viabilizar um sistema geográfico integrado de produção e troca, com vistas à acumulação capitalista.

De acordo com Escobar (2007), a pobreza e sua elevação à condição de ameaça foi uma "descoberta" do período pós Segunda Guerra Mundial, deslocando o discurso bélico para a seara do social e globalizando a dominação mundial dos EUA. Fundou-se um sentido moderno de pobreza massiva devido à expansão da economia de mercado, que privou pessoas de acesso à terra, à água e a outros recursos. Forjou-se, portanto, uma política da pobreza que criou consumidores e converteu os pobres em objeto de conhecimento e administração (ESCOBAR, 2007).

Sob o argumento do auxílio humanitário, os pobres da periferia do capitalismo se tornaram alvo de muitas políticas e programas oriundos de organizações internacionais, dentre elas: a Organização das Nações Unidas (ONU), o Banco Interamericano de Reconstrução e Desenvolvimento (BIRD), o Fundo Monetário Internacional (FMI), universidades, fundações e centros de pesquisa (ESCOBAR, 2007). De acordo com Banerjee (2003), o "Terceiro Mundo" nasceu a partir da invenção do subdesenvolvimento, fato histórico que enquadrou, automaticamente, mais de dois bilhões de pessoas em situação de subdesenvolvimento e representou o início de mais um processo de colonização e dominação das nações ricas e desenvolvidas sobre o restante do planeta.

Porto-Gonçalves (2015) ressalta que a solução apresentada para o subdesenvolvimento nada mais era do que o desenvolvimento nos moldes do padrão cultural europeu norte ocidental e estadunidense. Nesse sentido, a lógica do desenvolvimento implica a globalização da exploração da Natureza, sua submissão à lógica mercantil, com distribuição desigual de rejeitos e proveitos; a dominação de seres humanos sobre outros seres humanos e da cultura europeia sobre as demais culturas e povos (PORTO-GONÇALVES, 2015).

Furtado (1974) já advertia que a manutenção do subdesenvolvimento era funcional ao desenvolvimento dos países do polo dominante do padrão de poder mundial. Enquanto o referido autor ressaltava as diferenças que impactavam no desenvolvimento dos países subdesenvolvidos, Santos (2011) destaca a ação das corporações, chamando a atenção ao parasitismo do centro em relação à periferia, que é tomada pelo capital internacional para auferir altos lucros, vender a altos preços e obter produtos agrícolas e matérias primas a baixo custo.

O autor lembra que, na economia internacional capitalista, existem formações sociais dominantes e dependentes, produzindo uma oposição entre um capitalismo dominante e um 
dependente: "de um lado há um mercado global integrando trabalho e capital enquanto do lado hegemônico concentram-se tecnologia, produção e capitais" (SANTOS, 2011, p. 21). Essa dicotomia dominante-dependente se expressa na visão de Porto-Gonçalves (2015) numa "[...] separação entre os que produzem e os que consomem, entre os que ficam com os proveitos e quem ficam com os rejeitos [...]" (PORTO-GONÇALVES, 2015, p. 132).

O modelo desenvolvimentista se confrontou com questões ambientais na década de 1960, a partir da associação entre destruição do Meio Ambiente e crescimento econômico, contrariando a noção de desenvolvimento sustentada até a década de 1950, fazendo o mundo enxergar que desenvolvimento, por si só, não alcançava o equilíbrio ambiental e a equidade social (FOLADORI; TOMMASINO, 2000). Nesse sentido, destacam-se três fatos históricos: a publicação do livro de Rachel Carson, Primavera Silenciosa, em 1962; a Conferência da UNESCO sobre uso racional da biosfera, em 1968 (OLIVEIRA, 2008); e o informe para o Clube de Roma, Os Limites do Crescimento (1972) (FOLADORI; TOMMASINO, 2000).

Nos anos 1970, houve algumas respostas ao despontar da crise ambiental que contribuiu para colocar em questão o modelo desenvolvimentista. Em 1971, criou-se o Programa o Homem e a Biosfera na UNESCO (PEZZOLI, 1997). Em 1972, foi criado o Programa das Nações Unidas para o Meio Ambiente (PNUMA), que realizou a Conferência sobre Meio Ambiente Humano em Estocolmo, Suécia, introduzindo o debate sobre Meio Ambiente na agenda global, chegando a propor a diminuição do ritmo de crescimento econômico (OLIVEIRA, 2008).

No contexto da Conferência de 1972, o capital se defrontava com a perspectiva de um pensamento ecológico que pressupunha uma escolha entre crescer economicamente ou proteger o Meio Ambiente (LAYRARGUES, 1997). Os países ditos desenvolvidos haviam alcançado um elevado grau de industrialização e seus respectivos impactos no planeta já eram visíveis. Entretanto, os países ditos subdesenvolvidos, nos quais habitavam dois terços da população do planeta, reivindicavam as indústrias para seu desenvolvimento e solução das dificuldades sociais (CAPOBIANCO, 1992).

Tinha-se, então, "ao norte, os países cada vez mais limpos e ricos, graças à rígida legislação ambiental e à venda de suas indústrias poluidoras. Ao sul, a impressionante ampliação da degradação ambiental e da pobreza [...]" (CAPOBIANCO, 1992, p. 14). Com severas legislações ambientais no centro, as indústrias poluidoras, obsoletas, eletro intensivas e geradoras de produtos tóxicos começam a migrar para países da periferia dispostos a recebê-las. No final da década de 1970, havia se delineado um cenário da distribuição dos impactos ambientais entre polo dominante e polo dominado do padrão de poder mundial. 


\section{O desenvolvimento sustentável como modelo socioambiental global}

O Desenvolvimento Sustentável (DS) é um modelo socioambiental que se fez oportuno por produzir uma solução neoliberal para o incômodo que a problemática ambiental representava, desde os anos 1960, à reprodução do capital. Tal modelo, portanto, não é a renovação do modelo desenvolvimentista, mas sua continuidade. Trata-se de um projeto ecológico neoliberal (LAYRARGUES, 1997).

O modelo desenvolvimentista foi reelaborado, dando lugar a um "novo" modelo socioambiental a partir da invenção do DS pelo Relatório Brundtland, também intitulado "Nosso Futuro Comum", resultado do trabalho da Comissão Mundial sobre Meio Ambiente e Desenvolvimento (CMMAD), criada em de 1983 pela ONU e presidida por Gro Harlem Brundtland. A publicação de 1987 marca a origem do termo Desenvolvimento Sustentável (BANERJEE, 2003i MONTIEL; DELGADO-CEBALLOS, 2014; LANDRUM, 2017) e está vinculada à historicidade da reprodução do capitalismo (MOREIRA, 2010). O DS é "[...] aquele que atende às necessidades do presente sem comprometer as possibilidades de as gerações futuras atenderem a suas próprias necessidades [...]" (CMMAD, 1991, p. 46).

O DS é um modelo socioambiental que adiciona as dimensões social e ambiental à econômica. Dias (2011) afirma que essas três dimensões, ou o chamado triple bottom line, são difundidas como os três "P" da sustentabilidade - people (pessoas), planet (planeta) e profit (lucro). $O$ modelo socioambiental camufla as determinações históricas do processo produtivo no capitalismo, que se dá a partir da destrutividade socioambiental. Nesse sentido, o DS é um artifício do capitalismo para se naturalizar como único sistema econômico possível, atenuar as críticas contrárias, transformar a poluição industrial e a rarefação de recursos em novos campos de acumulação e, ainda, transferir o ônus da degradação aos países periféricos e classes subalternas (FREITAS; NÉLSIS; NUNES, 2012).

Por sua vez, o início dos anos 1990 foi marcado pelo fim da Guerra Fria², que culminou na desintegração da ex-União Soviética e fez a ajuda externa, em troca do apoio dos países pobres, perder o sentido (RUHIL, 2017). A partir de então, o modelo ocidental capitalista se expandiu globalmente pela via da abertura à lógica competitiva de mercado. O foco de organizações

${ }^{2}$ Conflito indireto entre os Estados Unidos da América (EUA), liderança capitalista, e a União das Repúblicas Socialistas Soviéticas (URSS), que buscava implantar o socialismo. Começou ao final da Segunda Guerra Mundial (1945) e terminou com a dissolução da URSS (1991). Conforme Alcadipani e Bertero (2012, p. 286), "o mundo da Guerra Fria era um mundo dividido entre dois modelos e modos de vida configurados como opostos. Tanto os EUA quanto a URSS procuravam abarcar o máximo de países e povos dentro de seu poder e influência". 
internacionais voltou-se para a erradicação da pobreza. A ajuda técnica dos países desenvolvidos passou a formar pessoas para atender ao mercado, enquanto a ajuda financeira destinava-se às ONGs e projetos governamentais. Desenvolvimento se relacionava, então, a criar condições de acesso ao consumo e modernização significava produzir para atender às necessidades infinitas dos consumidores, que desfrutavam da liberdade de escolha orientada pelo mercado (SANTOS FILHO, 2005). A "globalização neoliberal" marcou a década de 1990, no que tange ao aumento da concentração de riqueza nos países mais ricos: $0 \mathrm{G}^{3}$, com apenas $12 \%$ da população mundial e $16 \%$ da superfície planetária, concentrou 65\% de toda produção global (PORTO-GONÇALVES, 2015).

De acordo com Porto-Gonçalves (2015), tal feito só foi possível porque "[...] o fluxo de matérias-primas e de energia continuou a fluir no sentido colonial tradicional, ou seja, em direção aos países situados no polo dominante do padrão de poder mundial [...]". Desse modo, o DS acontece no seio de escancarada desigualdade entre classes sociais, territórios e países, justamente porque "[...] é a exploração das populações dessas áreas que tem tornado possível a sustentabilidade ecológica do atual padrão de poder mundial [...]" (PORTO-GONÇALVES, 2015, p. 42). É oportuno ressaltar que houve um deslocamento proposital do foco, que se voltou para a pobreza por si mesma, deixando de lado, portanto, a discussão sobre a desigualdade na distribuição e apropriação da riqueza no mundo. Fez-se da pobreza, e não da riqueza, a razão da degradação ambiental (BANERJEE, 2003).

Na periferia do capitalismo, o movimento de privatizações e o enfraquecimento do papel estatal trouxeram consequências agravantes, como desemprego e aumento da pobreza, ainda que estivessem levantadas as bandeiras pela sua redução e eliminação (LOPES, 2005). Segundo Ruhil (2017), foi na década de 1990 que os eventos liderados pela ONU alcançaram relevância, pois os Programas de Ajuste Estrutural (PAE) do Banco Mundial provocaram aumento da pobreza e da desigualdade. Os PAE resultaram em consequências sociais dramáticas devido ao aprofundamento da pobreza na África subsaariana, na América do Sul e nos países em transição da Europa e da Ásia Central (FROGER, 2006). Restou, destarte, a viabilização de alternativas, seja pela ONU ou via organizações não governamentais locais e internacionais. As leis do mercado tornaram-se doutrina universal e o desenvolvimento se reduziu às iniciativas humanitárias do Fundo das Nações Unidas para a Infância (UNICEF) e das ONGs (RIST, 2002).

O modelo socioambiental vigente, consensualmente forjado como DS, é ditado a partir do centro para a periferia, seguindo um movimento histórico de relação entre polo dominante e polo dominado. Conforme Banerjee (2003), as soluções para questões ambientais, oriundas do centro

\footnotetext{
3 Formado pelos países com alto nível de industrialização e com maior poder econômico do planeta: Alemanha, Canadá, Estados Unidos, França, Itália, Japão e Reino Unido.
} 
industrializado, perenizam as relações colonialistas de dependência estabelecidas com a periferia, uma vez que não há o reconhecimento da sua responsabilidade pelo fato de as regiões mais pobres destruírem ou exportarem Natureza para atender às demandas do centro e do serviço da dívida, decorrentes da austeridade imposta pelo Banco Mundial.

A crítica contundente de Porto-Gonçalves (2015) revela que há uma posição desigual na distribuição, tanto dos proveitos quanto dos rejeitos. A Natureza tem sido mercantilizada em uma lógica acima das possibilidades de existência do planeta, dando destaque para a colonialidade do poder, a partir do predomínio do polo dominante do padrão de poder mundial (países hegemônicos, cêntricos) sobre a periferia, uma vez que é "a exploração das populações dessas áreas que tem tornado possível a sustentabilidade ecológica do atual padrão de poder mundial que vem se mantendo não só extremamente desigual como se polarizando ainda mais" (PORTO-GONÇALVES, 2015, p. 42).

A formação do excedente e a mais-valia gerada pelo polo dominado têm sustentado os países do polo dominante do padrão de poder mundial. A periferia continua sendo o alicerce, através da acumulação por expropriação, que o polo dominante necessita, para a consolidação do modo de produção capitalista. Os países periféricos asseguram a produção e a reprodução dos países industrializados às custas da produção primária, das suas riquezas e das variedades ambientais. A periferia continua a sofrer os efeitos de um subdesenvolvimento em decorrência da divisão internacional do trabalho, do intercâmbio desigual de mercadorias e da degradação ambiental, além de se manter no fornecimento das bases materiais para a acumulação de capital do polo dominante (FREITAS; NÉLSIS; NUNES, 2012).

A Conferência Rio-92 difundiu globalmente o modelo de desenvolvimento socioambiental vigente, tornando-o um consenso planetário, seja na esfera pública, no mercado ou no âmbito da sociedade civil. Segundo Layrargues (1997), o termo não só se tornou legítimo como foi absorvido definitivamente pelos ambientalistas. Para Moreira (2010, p. 88), o discurso da sustentabilidade apresenta um poder consensual para manter o modo produtivo, sob a égide do capital, forjando "[...] a ideia de um problema em comum, em que todos os países, indivíduos e classes sociais comungam da mesma culpa, e por isso da mesma responsabilidade [...]". Além do poder consensual, sua força está na capacidade de se tornar atrativo para uma diversidade de interesses: do mercado, dos estados e da sociedade civil, pois serve a interesses opostos, oferecendo visões específicas a cada uma das esferas econômica, social e ambiental (PATTBERG, 2009).

Ruhil (2017) destaca que, em 1995, houve a realização da cúpula mundial de desenvolvimento social, com o objetivo de reduzir a pobreza e que o ano de 1996 foi declarado, oficialmente, pela ONU, como o ano internacional para sua erradicação. Segundo Pezzoli (1997), uma série de outras importantes conferências se seguiram à Rio-92, denominadas de Rio Cluster, responsáveis por 
fomentar o interesse pela sustentabilidade do nível local ao global. Nos anos 2000, por meio da Cúpula do Milênio da ONU em Nova lorque, os Objetivos de Desenvolvimento do Milênio (ODM) vieram à pauta (ONU, 2000). Veiga (2015) critica tais objetivos, pois apenas um deles expressa a preocupação ambiental e porque a noção de sustentabilidade aparece restrita à questão ambiental.

Conforme Lautier (2010), a agenda do desenvolvimento foi invadida pelos consensos, cuja função é "[...] matar o debate e, ao mesmo tempo, submeter aqueles que aderem a ele, mesmo sem acreditar muito, em nome do menos pior ou na falta de algo melhor [...]" (LAUTIER, 2010, p. 356). O dito de Lautier (2010) está em consonância com Muñoz (2008), que considera que os de Desenvolvimento do Milênio representaram nada mais do que um consenso de mínimos sociais. $A$ formação do consenso em torno do DS também é ressaltada por Nobre (2002, p. 25), ao criticar a imprecisão do termo, "[...] não só como uma noção fadada a produzir consenso, mas também como um enigma a ser criticado por sua vaguidão, imprecisão e caráter contraditório [...]".

Durante a Rio +20 foi emitido um documento intitulado "O futuro que queremos", que deu origem a um segundo documento intitulado "Transformando nosso mundo: a agenda 2030 para o desenvolvimento sustentável". Este último criou os Objetivos de Desenvolvimento Sustentável (ODS), com vistas à gestão global da sustentabilidade. Tais objetivos, em 2015, substituíram, durante a Cúpula das Nações Unidas sobre o desenvolvimento sustentável, em Nova lorque, os antigos de Desenvolvimento do Milênio (VITALE; SANTOS NETO, 2016).

Os ODS são a mais recente abordagem para a governança global do Desenvolvimento Sustentável (BIERMANN; KANIE; KIM, 2017). Nessa governança, instituições formais e informais, organizações internacionais, grupos científicos transnacionais, sociedade civil e o setor privado têm central importância na implementação do modelo socioambiental vigente (LIMA, 2012). Observa-se como esta perspectiva de governança vem se operacionalizando na gestão do desenvolvimento sustentável a partir dos ODS, uma vez que sua implementação implica a atuação de governos, sociedade civil, setor privado, academia, mídia, e Nações Unidas em um arranjo global (IVO, 2016).

Os Objetivos de Desenvolvimento do Milênio fazem uso de metas globais não vinculantes, estabelecidas pelos estados membros da ONU. Os governos não têm obrigação legal de transferir formalmente as metas para seus sistemas jurídicos nacionais, o que lhes diferenciam das outras metas ou objetivos ambientais globais sobre DS, que estão consagrados em tratados legalmente vinculantes como é o caso, por exemplo, da proteção da camada de ozônio. Por isso, a governança por metas opera através de arranjos institucionais frouxos no nível intergovernamental, uma vez que a supervisão institucional da sua implementação em nível global foi deixada bastante vaga. São 169 alvos para orientar a implementação das 17 metas. No entanto, muitos desses alvos são qualitativos e conferem aos governos a máxima liberdade na sua interpretação e implementação (BIERMANN; KANIE; KIM, 2017). 
Na governança global do Desenvolvimento Sustentável, o mercado exerce forte influência, as grandes corporações influenciam as políticas ambientais e comerciais da Organização Mundial do Comércio $(\mathrm{OMC})$ e de outros acordos globais. As empresas figuram como agentes poderosos no avanço dos discursos do desenvolvimento sustentável no campo organizacional da governança global (BANERJEE, 2003). Dentre os protagonistas que mais têm se beneficiado, a partir da Conferência Rio 92, no campo da governança global do DS, destacam-se as corporações transnacionais, grandes ONGs e os gestores do Banco Mundial, Fundo Monetário Internacional e Organização Mundial do Comércio (PORTO-GONÇALVES, 2015).

Nesse contexto, ocorre uma fusão ou confusão entre o poder político e o econômico a partir da relação entre empresas transnacionais, poderes políticos nacionais e organizações internacionais. Há um movimento que prioriza as empresas e busca atender à gestão dos interesses do grande capital. No âmbito da ONU, as empresas se destacaram pela posição hegemônica planetária, derivada do seu poderio econômico e financeiro, enquanto governos e estados nacionais reduziramse à função de gestores do sistema dominante (TEITELBAUM, 2010).

Desde então, os organismos da ONU têm convergido ao financiamento privado e demonstrado a tendência aos programas que interessem às empresas, aos EUA e demais países ricos (TEITELBAUM, 2010). As empresas são designadas, pela ONU, como atores sociais, sendo aproximadas, discursivamente, das organizações da sociedade civil. Este feito se deu, principalmente, a partir do Pacto Global, como uma tentativa de estender o sentido de participação às empresas. Destaca-se a aliança entre a ONU e os interesses privados de uma elite econômica internacional, evidenciando a influência das corporações transnacionais nas decisões tomadas pelos organismos que a compõem (TEITELBAUM, 2010).

Os anos 1990 representaram um marco para um direcionamento à lógica empresarial em todos os fóruns internacionais, nos quais se debateu a questão ambiental (PORTO-GONÇALVES, 2015). Em 1992, houve tanto a fundação do World Business Council for Sustainable Development (WBCSD), quanto foi publicado o Changing Course - estudo sobre o papel das empresas no Desenvolvimento Sustentável. Maurice Strong, líder empresarial canadense e Secretário Geral da Conferência Rio-92, contratou Stephan Schmidheiny, principal autor do referido estudo, como coordenador de contribuições corporativas nesta cúpula. A partir de tal articulação, as empresas têm sido reconhecidas e aceitas como atores legítimos no discurso sobre DS. Assim, ao invés de ser visto como parte do problema ambiental, o mercado, a partir do início dessa década, passou a ser visto como parte da sua solução (PATTBERG, 2009).

Um marco do avanço da lógica mercantil da sustentabilidade no universo empresarial, no final da década de 1990, foi a criação da Global Reporting Initiative (GRI), organização sem fins lucrativos, fundada em Boston em 1997, que concebeu, em 2000, a primeira estrutura padronizadora para 
Relatórios de Sustentabilidade. Tal Organização é responsável por criar, aprimorar e difundir a prática corporativa de comunicar os resultados por meio dos relatórios anuais de sustentabilidade.

Para Landrum (2017), o DS é tratado, inicialmente, nas políticas e abordagens de desenvolvimento econômico no âmbito governamental, a partir de sua regulação sobre o Meio Ambiente. À medida que os governos o fazem, as empresas, que também operam sob certos limites políticos e regulatórios dos governos, adotam a sustentabilidade, que configura a contribuição dos negócios para alcançar o DS - modelo socioambiental que se tornou consenso no capitalismo desde a Conferência Rio-92. Landrum (2018) aponta uma possibilidade de diferenciar o DS da sustentabilidade, tratando por sustentabilidade corporativa aquela concebida no nível micro da empresa, enquanto que o DS seria uma ideação de nível macro ou societal (LANDRUM, 2017).

Apesar de, cada vez mais, empresas introduzirem a sustentabilidade nos negócios (SZÉKELY; KNIRSCH, 2005), o Meio Ambiente permanece sendo degradado continuamente (LANDRUM, 2017). É a partir desta contradição que a sustentabilidade empresarial é percebida, neste trabalho, como uma transfiguração, um deslizamento do lugar do DS. Há um trabalho ideológico de mobilização de sentidos em torno da preocupação com a Natureza para buscar encobrir os reais motivos pelos quais as empresas tratam da sustentabilidade. Ainda que a realidade revele o contrário, parece haver uma insistência das empresas em manter, discursivamente, a ideia de sustentabilidade corporativa.

A noção de transfiguração aqui utilizada tem a ver com o fato de que "[...] na constituição dos sentidos eles podem sofrer um deslizamento, um processo de transferência que faz com que apareçam como deslocados" (ORLANDI, 1993b, p. 7). Nessa perspectiva, a sustentabilidade empresarial funciona como um discurso (PRATES, 2013). É resultado de um trabalho ideológico de organização de sentidos que opera um deslocamento, uma transfiguração, ao transformar o DS em sustentabilidade, que soa mais positiva e converte-se, logo em seguida, em sustentabilidade corporativa. Vê-se, então, que os discursos corporativos de sustentabilidade se deslocam da sustentabilidade planetária global para a sustentação da empresa por meio de oportunidades de crescimento (BANERJEE, 2003).

No entanto, segundo Montiel e Delgado-Ceballos (2014), não está explicitado o que significa sustentabilidade corporativa, nem mesmo para os estudiosos de negócios. Falta, ainda, uma definição comum. Por se tratar de um conceito emergente no campo da gestão, houve um aumento exponencial em atividades relacionadas a este tema, crescente contratação de professores especializados nas escolas de negócios em todo o mundo e também de funcionários para atuar nas grandes empresas. É certo, entretanto, que a designação sustentabilidade tem origem no DS (ICHIKAWA; CARRIERI, 2014; FARIA, 2014; MONTIEL; DELGADO-CEBALLOS, 2014). O léxico expandiu-se para abarcar os termos responsabilidade corporativa, responsabilidade social 
corporativa, responsabilidade social empresarial, cidadania corporativa, desempenho social corporativo, sustentabilidade corporativa e gestão ambiental (LANDRUM, 2017).

Cabe lembrar que a designação sustentabilidade vem de sustainability, expressão que significa assegurar que os processos produtivos e de prestação de serviço não comprometam a existência de suas fontes, mas sim, garantam a reprodução de seus meios (FARIA, 2014). Entretanto, as designações sustentabilidade e DS têm sido empregadas de maneira intercambiável (BANERJEE, 2003). Quando os substantivos desenvolvimento e sustentável se unem, eles produzem um efeito de sentido de sustentação da reprodução do capitalismo. Sustentabilidade, nesse contexto, tem a ver com a sustentação do crescimento do consumo material (LELÉ, 1991). A sustentabilidade foi absorvida pela empresa como prática de mercado. Conforme Lelé (1991), a noção dominante de DS resguarda o sistema capitalista de mudanças que possam afetá-lo substancialmente.

O modelo socioambiental vigente é ocidental, foi concebido por um sistema unitário de conhecimento, o colonial, ou, como diz Porto-Gonçalves (2015): a colonialidade do saber e do poder. O DS permanece, no entanto, subordinado ao paradigma econômico dominante, privilegiando as noções ocidentais de ambientalismo e conservação (BANERJEE, 2003). Layrargues (1997) acusa o modelo vigente de pressupor o mercado total, de assumir a ideologia neoliberal, uma vez que evita discutir um teto máximo e até mesmo a redução do consumo dos países desenvolvidos para equilibrar com os países mais pobres. DS, segundo o referido autor, é um subterfúgio, uma fuga ao debate, já que propõe um piso, omitindo-se do peso da responsabilidade da poluição e da riqueza. O autor afirma, ainda, que a preocupação do DS é preservar a perspectiva dominante de desenvolvimento, representando o desenvolvimentismo em nova roupagem, mantendo inalterada sua estrutura de funcionamento, que é dependente da lógica capitalista de mercado.

Na lógica de mercado, à sustentabilidade subjaz a racionalidade econômica (LEFF, 2009). Para Banerjee (2003), o DS é um paradigma de desenvolvimento baseado na racionalidade econômica e não numa racionalidade ecológica. Nesse sentido, o mercado adota a sustentabilidade mais como "práticas identificadas com a ecoeficiência e a produção mais limpa do que uma elevação do nível de consciência do empresariado em torno de uma perspectiva de um desenvolvimento econômico mais sustentável" (DIAS, 2012, p. 43).

A sustentabilidade empresarial mantém a lógica da produção e do processo de acumulação inalterada (FARIA, 2014). A junção entre sustentabilidade e desenvolvimento é bastante contraditória e, portanto, falaciosa, uma vez que se insere no capitalismo, um sistema cuja lógica de acumulação não tem permitido, de fato, que as dimensões social e ambiental tenham a mesma prioridade que a dimensão econômica, o que é notório, uma vez que o modo de produção inerente a tal sistema pressupõe um "[...] consumo destrutivo da natureza que vai degradando o ordenamento ecológico e minando suas próprias condições de sustentabilidade [...]" (LEFF, 2009, p. 27). 
Para Harvey (2013), o capitalismo está num processo desenfreado de acumulação, situado histórica e geograficamente. O autor parte daquilo que Karl Marx denominou de acumulação primitiva, redefinindo-a como acumulação por espoliação, uma atualização do conceito marxiano, que se exemplifica por: expulsões de povos do campo; coexistência com a agricultura familiar em benefício do agronegócio; apropriação e cooptação de realizações culturais e sociais anteriores ao capitalismo; biopirataria; mercadificação da natureza; corporativização e privatização de bens e utilidades públicas, utilizando-se do poder do Estado para tal.

Tanto a designação sustentabilidade quanto o termo DS se inserem em uma perspectiva de desenvolvimento capitalista. O DS é, segundo Layrargues (1997), um projeto ecológico neoliberal, produtor da ilusão de um tempo de mudanças graduais para o alcance da sustentabilidade socioambiental. Esta visão é complementar à de Nobre (2002), para quem o DS é um princípio discursivo de aceitação universal, solução que foi encontrada para gerar uma saída ao impasse da ausência de crescimento e cuja força "[...] está exatamente em ter dito: desenvolvimento e meio ambiente não são contraditórios [...]" (NOBRE, 2002, p. 45). Passados alguns anos de tal constatação, "[...] o projeto atual de sustentabilidade desloca política e ideologicamente o sentido de desenvolvimento à necessária continuidade e expansão da riqueza capitalista [...]" (MOREIRA, 2010, p. 100).

O relatório Brundtland, por meio do DS, criou e impôs uma lógica de mundo (VISVANATHAN, 1991). Esta lógica conforma um modelo socioambiental de desenvolvimento que se tornou um consenso planetário difundido a partir da conferência da ONU no Rio de Janeiro em 1992. Segundo Veiga (2015), autores como Escobar e Rist declaram que as adjetivações de "social" e "sustentável" atribuídas ao termo desenvolvimento não são mais do que fraudes, pois "[...] seja qual for o adjetivo que lhe seja posto, o conteúdo implícito ou explícito do desenvolvimento se resumiria ao crescimento econômico [...]" (VEIGA, 2015, p. 51). Segundo Porto-Gonçalves (2015), há uma assimilação da questão ambiental pela lógica do mercado, legitimada pela globalização neoliberal, que representa um período sem igual, no que diz respeito à devastação do planeta.

\section{Pressupostos teórico-metodológicos na análise do discurso}

O presente trabalho está alicerçado na Análise do Discurso (AD) fundada por Michel Pêcheux, que considera o discurso como efeito de sentidos entre interlocutores (PÊCHEUX, 2016). Não se extrai simplesmente o sentido do texto, antes o analista apreende sua historicidade, pondo-se numa relação de confronto de sentidos. A AD não se deixa utilizar como instrumento neutro, por isso, para Pêcheux, o discurso é o instrumento da prática política (ORLANDI, 1990). 
Conforme explica Maldidier (2014, p. 22), "a análise (do discurso) só pode ser pensada em relação a uma teoria (do discurso) [...]". A partir da relação entre a estrutura e o acontecimento, o discurso é analisado por meio de "[...] um batimento entre descrição e interpretação, procurando explicitar o funcionamento do discurso [...]" (ORLANDI, 2016, p. 31). A análise é, ademais, uma interpretação do processo de formulação relacionado à situação concreta de quem formula o enunciado (AMARAL, 2007).

A abordagem metodológica é qualitativa e tem como fonte documentos escritos de natureza oficial (GODOY, 1995), para explicar um acontecimento, "[...] por meio de conceitos existentes ou emergentes [...]" (YIN, 2016, p. 7). Para subsidiar a Análise do Discurso, adotamos a pesquisa documental que, conforme Yin (2016), chama atenção para a recolha de objetos, dentre eles documentos, artefatos e registros arquivais, que tenham relação com o objeto de estudo e que podem gerar dados verbais, pictóricos, numéricos ou gráficos.

Segundo Phillips e Hardy (2002), são consideradas materialidades para análise do discurso: interações não verbais, textos escritos, conversas, filmes, interações não verbais, entre outros. Dentre as fontes de texto, em uma organização, os autores citam, dentre outros, relatórios. Para esta pesquisa, retirou-se a sequência discursiva de referência de e valores referentes ao lucro dos relatórios anuais de sustentabilidade da Vale.

Courtine (2014) define sequência discursiva (SD) como uma sequência oral ou escrita de dimensão superior à frase. A SD é a manifestação da realização de um intradiscurso (COURTINE, 2016) e serve como ponto de referência a partir do qual se dá o gesto de interpretação. Ainda de acordo com Courtine (2016), a sequência linguística é a reformulação de um enunciado, lugar no qual se materializam elementos de saber de uma formação discursiva (FD), representando o intradiscurso.

O ponto de partida desta análise foi uma sequência discursiva de referência, extraída do Relatório de Sustentabilidade da Vale do ano de 2011, considerada enquanto superfície discursiva (intradiscurso). O Desenvolvimento Sustentável é considerado como modelo socioambiental vigente, constituído na formação discursiva do desenvolvimento capitalista, que disponibiliza um conjunto de formulações com as quais a sequência discursiva de referência mantém relações interdiscursivas.

\section{Mercado e estado: uma parceria que privatiza bens naturais coletivos e externaliza os danos socioambientais da mineração}

A empresa Vale tem origem nas reservas de minério de ferro no estado de Minas Gerais, em 1910, adquiridas por meio da companhia inglesa Brazilian Hematite Syndicate. Em 1911, o grupo inglês organizou a Itabira Iron Ore Company, posteriormente comprada por capital estadunidense e transformada em Companhia Vale do Rio Doce em 1942. Em 1949, a Vale já exportava 80\% do minério 
de ferro produzido no Brasil. Em 1967, estava entre as seis maiores exportadoras de minério de ferro do mundo, alcançando a liderança deste mercado em 1975 (ADÃO, 2006).

Em 1993, tornou-se a maior produtora de ouro da América Latina (RUSSO, 2002). A inclusão da estatal no Plano Nacional de Desestatização provocou duas ações diretas de inconstitucionalidade (ADIN), com o argumento principal de que a entrada da companhia no referido Plano tinha que se dar por lei e não por decreto. Além das ações acima citadas, outras 58 ações contra o processo de venda, por questões diversas. O Consórcio Brasil, encabeçado pela Companhia Siderúrgica Nacional, "[...] arrematou 41,73\% das ações ordinárias do Governo Federal por US\$3,338 bilhões [...]" (RUSSO, 2002, p. 45).

A Companhia Vale do Rio Doce foi privatizada em 07/05/1997 (DALLA COSTA, 2009; GODEIRO; MOURA; SOUZA; VIEIRA, 2007), acontecimento que marcou sua entrada no mundo globalizado dos negócios, constituindo-se em ícone da agenda renitente de privatizações na década de 1990 no Brasil. Em 1997, com valor de mercado estimado em US\$ 8,6 bilhões, a empresa passou por uma reestruturação que dispensou cinco mil funcionários públicos (RUSSO, 2002). Em 1998, o lucro da empresa cresceu 46\% e, em 1999, alcançou o montante de US\$1,251 bilhões. Em 2003, o valor da Companhia atingiu US\$21,762 bilhões e, devido à parceria com a empresa japonesa Mitsui, o lucro atingiu US\$4,509 bilhões, "[...] recuperando em um ano, o preço pago pelos compradores no leilão de privatização [...]" (GODEIRO; MOURA; SOUZA; VIEIRA, 2007, p. 12).

O discurso favorável à privatização mobilizou sentidos em torno de uma Companhia deficitária e do monopólio estatal como causa da ineficiência no mercado. Entretanto, a Vale privada ampliou ainda mais o monopólio na produção de minério de ferro, passando de 65\% em 1999 para cerca de $90 \%$ na segunda metade dos anos 2000 , determinando o valor do minério a seu critério (GODEIRO; MOURA; SOUZA; VIEIRA, 2007). Desde então, o valor de mercado da Vale tem crescido continuamente. Em 2018, chegou perto dos $\mathrm{R} \$ 300$ bilhões ${ }^{4}$ e fez a corporação ocupar a vice-liderança da Bolsa de Valores no Brasil, como a segunda empresa mais valorizada.

A Sequência Discursiva de Referência (SDR) analisada neste trabalho foi escolhida porque materializa o discurso do mercado que foi constituindo-se a partir do relatório Brundtland, forjando um modelo socioambiental, cujo objetivo central é remover a contradição inerente ao capitalismo, entre desenvolvimento e preservação da Natureza (NOBRE, 2002).

\footnotetext{
4 Segundo matéria no Valor (https://economia.estadao.com.br/noticias/mercados, vale-vira-vice-lider-da-bolsa-brasileira-e-fica-atras-soda-ambev,70002340902). A mesma informação consta, ainda, no site da Vale (http://www.vale.com/brasil/PT/aboutvale/news/Paginas/vale-atinge-maior-valor-mercado-ultimos-seteanos.aspx).
} 
SDR - Mineração e meio ambiente: uma parceria possível (VALE, 2011, p. 55)

Na SDR há uma declaração afirmativa com o sujeito composto por dois substantivos: meio ambiente e mineração, este último evoca o sentido de mercado - o ramo industrial que, no Brasil, se tornou um dos principais setores da economia (SILVA, 2007). O mercado da mineração no Brasil está privatizado e liberalizado desde o final dos anos 1990, marcadamente pela desestatização da então Companhia Vale do Rio Doce em 1997.

O modelo de acumulação capitalista em curso tende a intensificar a expansão de projetos direcionados a controlar a extração e exportação de commodities em larga escala. Nesse modelo, a América Latina representa um estoque indispensável de recursos estratégicos, tais como água, energia, minério e biodiversidade. Portanto, o padrão extrativo-exportador em curso, baseado na exploração da Natureza pelas corporações transnacionais ganhou relevância na economia regional. A demanda asiática, adicionada ao vasto estoque descoberto entre as décadas de 1990 e 2000, elevou a América Latina à posição de destinatária de investimentos, destacando-se Brasil, Peru e Chile (SCOTTO, 2013).

Tendo em vista que o setor de mineração lidera a exportação na maioria dos países latinoamericanos, os governos têm, não só assegurado a continuidade ou expansão da atividade empresarial, mas também negligenciado a reivindicação da sociedade por proteção ambiental e justiça para as violações das empresas (ARAÚJO; FERNANDES, 2016).

Enquanto o setor primário e de serviços na economia brasileira se expandiu desde a década de 1990, a indústria manufatureira teve sua redução intensificada nas últimas décadas, configurando a reprimarização da economia (ROCHA; PORTO; PACHECO; LEROY, 2017). Oreiro e Feijó (2010) explicam que a reprimarização reverte a pauta exportadora na direção de commodities, produtos primários e manufaturas de baixo valor adicionado ou baixo conteúdo tecnológico. Este processo guarda estreita relação com o aprofundamento das políticas de liberalização e abertura brasileira aos produtos importados e à escolha política de especializar o Brasil como exportador de comoddities minero-agrícolas.

A reprimarização reduz empregos demandantes de mão-de-obra qualificada, ao mesmo tempo em que gera empregos que tendem a baixas remunerações e às mais precárias condições de trabalho (ROCHA; PORTO; PACHECO; LEROY, 2017). Tendo em conta que este movimento de reprimarizar é uma escolha política, em acordo com os interesses do capital, o que comparece na SDR como parceria tem a ver também com a luta de classes. Nesse sentido, o capital, juntamente com o apoio do Estado, viabiliza um processo gerador de empregos com remunerações baixas e condições precárias de trabalho, com vistas a aumentar o lucro do capital, sacrificando, portanto, a classe que vive do trabalho. 
O predicado da SDR realiza uma estreita parceria, cuja legitimidade foi antes chancelada pelo Relatório Brundtland, pois a sustentabilidade alia e relaciona preservação e desenvolvimento (MOREIRA, 2010). Como Layrargues (1997) complementa, depois do advento das chamadas tecnologias limpas, consideradas como vantagem competitiva, desenvolvimento e Meio Ambiente, de uma relação de antagonismo, passaram à relação de complementaridade.

Trata-se de um sujeito composto: a mineração, que representa o mercado; e o Meio Ambiente, que é regulado e tutelado pelo Estado. Em tão pouco tempo, e com número reduzido de países produzindo para atender à demanda global de minérios, parece ingenuidade defender que, nessa relação, o Meio Ambiente tenha sido favorecido. Wanderley, Mansur, Milanez e Pinto (2016) revelam que, em 2013, cerca de dois terços das exportações globais de minérios concentraram-se em apenas cinco países. O Brasil, em segunda colocação, foi responsável por 14,3\% do minério produzido no planeta. O período vertiginoso de produção durou de 2003 a 2013, caracterizando o megaciclo das commodities, no qual as importações globais de minérios aumentaram 630\% e a tonelada do minério de ferro passou de US\$32,00 (2003) a US\$ 196,00 (2008), caindo para US\$53,00 em 2011 (WANDERLEY; MANSUR; MILANEZ; PINTO, 2016, p. 30).

Os lucros da Vale durante esse megaciclo, conforme dados do Quadro 1, aumentaram consideravelmente, alcançando em 2011 um montante quase multiplicado por dez, em relação a 2003. É perceptível, ainda, a tendência de queda depois de 2011, que pode estar relacionada ao que foi posto por Wanderley, Mansur, Milanez e Pinto (2016).

Quadro 1 - Lucro líquido da Vale no período 1997-2018 (em milhões de R\$)

\begin{tabular}{|l|l|l|l|l|l|}
\hline \multicolumn{1}{|c|}{ Anos 90 } & \multicolumn{1}{c|}{ Lucro } & \multicolumn{1}{|c|}{ Anos 2000 } & \multicolumn{1}{c|}{ Lucro } & \multicolumn{1}{c|}{ Anos 2010 } & \multicolumn{1}{c|}{ Lucro } \\
\hline- & - & 2001 & 3.051 & 2011 & 37.400 \\
\hline- & - & 2002 & 2.043 & 2012 & 9.233 \\
\hline- & - & 2003 & 4.509 & 2013 & $115^{5}$ \\
\hline- & - & 2004 & 6.460 & 2014 & 353 \\
\hline- & - & 2005 & 10.443 & 2015 & $-45.997^{6}$ \\
\hline
\end{tabular}

${ }^{5} \mathrm{~A}$ demonstração de resultado no endereço eletrônico da Vale aponta um prejuízo de $\mathrm{R} \$ 258$ milhões. Entretanto, há um esclarecimento em matéria do G1Economia Negócios de 26/02/2014: "A Vale registrou lucro líquido $\mathrm{R} \$ 115$ milhões em 2013, segundo balanço divulgado nesta quarta-feira (26). O resultado foi $98,8 \%$ menor que o de 2012, quando a empresa teve ganhos de $\mathrm{R} \$ 9,89$ bilhões. (Correção: ao ser publicada, essa reportagem informava no título que a Vale teve prejuízo de $R \$ 258$ milhões em 2013. O resultado negativo faz parte do balanço da empresa, mas é considerado no cálculo ajustado do Ebitda, lucro antes de juros, impostos e outras amortizações.)" (grifo da reportagem).

${ }^{6} \mathrm{Em}$ reportagem de 25/02/2016 do portal G1 Economia Negócios, tem-se que "entre os fatores para essa piora, a companhia cita os maiores "impairments" no ano passado - instrumento que adequa o ágio pago nas 


\begin{tabular}{|l|l|l|l|l|l|}
\hline \multicolumn{1}{|c|}{ Anos 90 } & \multicolumn{1}{|c|}{ Lucro } & \multicolumn{1}{|c|}{ Anos 2000 } & \multicolumn{1}{c|}{ Lucro } & \multicolumn{1}{c|}{ Anos 2010 } & \multicolumn{1}{c|}{ Lucro } \\
\hline- & - & 2006 & 13.431 & 2016 & $3.976^{7}$ \\
\hline 1997 & 756 & 2007 & 20.000 & 2017 & 17.670 \\
\hline 1998 & 1.029 & 2008 & 21.279 & 2018 & $25.657^{8}$ \\
\hline 1999 & 1.251 & 2009 & 10.249 & - & - \\
\hline 2000 & 2.133 & 2010 & 30.422 & - & - \\
\hline
\end{tabular}

Fonte: Elaboração dos autores a partir de Dalla Costa (2009); VALE (2017C); G1 (2016).

A Vale apresenta, no relatório publicado em 2017, alguns resultados ilustrativos de quão promissora tem sido, para o mercado, uma parceria que dissimula os danos ambientais causados pela mineração. Alguns indicadores oferecem um parâmetro para identificar os resultados da Vale em 2016: a geração de caixa operacional, medida pelo EBITDA ${ }^{9}$ ajustado, foi de US $\$ 12,2$ bilhões, o que representou $72 \%$ a mais do que os US\$ 7,1 bilhões obtidos em 2015. A Vale fez um investimento de US $\$ 5,5$ bilhões em crescimento e manutenção e obteve produção recorde: minério de ferro, com 348,8 megatoneladas em Carajás; níquel, com 311.000 toneladas na Nova Caledônia; e cobre, com 453.000 toneladas em Salobo ${ }^{10}$. O lucro líquido, obtido no ano, foi de US\$ 4 bilhões.

Se do lado do mercado, os resultados são expressos por recordes de produção, do lado do Meio Ambiente um recorde se destaca do ponto de vista do potencial destrutivo da mineração. Diversos autores afirmam que há muitos impactos econômicos, sociais e ambientais negativos em atividades extrativistas, como a mineração (GUDYNAS, 2009; MILANEZ; SANTOS, 2013; ROCHA; PORTO; PACHECO; LEROY, 2018; TETREAULT, 2013). A Sequência analisada, entretanto, silencia os conflitos e impactos históricos, produzindo um efeito de relação harmônica entre capitalismo e Natureza.

Tetreault (2013) apresenta impactos da mineração, tais como: destruição da terra, da flora e fauna na foz das minas, além da geração de bilhões de toneladas de resíduo (sólidos ou tanques de rejeito) que contaminam o Meio Ambiente pela ação do vento, da chuva, da gravidade ou por

aquisições no exterior à realidade atual do mercado - e à depreciação de $47 \%$ do real contra o dólar" (PORTAL G1, 2019).

'Este valor foi retirado do documento demonstrações financeiras para 2016, entretanto no mesmo documento para 2017 o valor do lucro aparece como $\mathrm{R} \$ 13.296$ milhões.

${ }^{8}$ Valor disponível em Portal G1, 2019. Segundo a reportagem "A Vale registrou lucro líquido de $R \$ 25,657$ bilhões em 2018, de acordo com balanço divulgado nesta quarta-feira (27) pela companhia. O desempenho foi o melhor desde 2011 e representou uma alta de $45,6 \%$ na comparação com o ano anterior".

'EBITDA vem do inglês "earnings before interest, taxes, depreciation and amortization", traduzido como LAJIDA (lucro antes dos juros, impostos, depreciação e amortização).

${ }^{10} \mathrm{~A}$ Vale aprovou investimentos de US $\$ 1,1$ bilhão para expansão, o projeto Salobo III, em Canaã dos Carajás (PA), cuja capacidade atual é de 200 mil toneladas de cobre contido em concentrado por ano. A previsão do início da operação comercial é 2022 (COBRE, 2018). 
acidentes frequentes. $O$ autor destaca, também, que o processamento do minério demanda elevado consumo de energia, emprega substâncias altamente tóxicas e requer o consumo de grandes quantidades de água. Conforme Gudynas (2009), o extrativismo provoca graves impactos sociais e ambientais desde a acentuação das desigualdades locais a casos de polvição e perda de biodiversidade. Segundo o referido autor, a situação comum é a externalização dos danos sociais e ambientais.

No Brasil, os direitos sociais, trabalhistas e ambientais são frágeis e desrespeitados e os riscos se convertem em externalidades. Há uma gestão de baixo nível, causadora de degradação ambiental e mortes, corriqueiramente não assumidas pelas empresas responsáveis, uma vez que primam pelo aumento da produção para obter maiores lucros. Destarte, os custos das externalidades negativas devido à poluição, mortes e degradação ambiental são socializados num processo invisível à sociedade e terminam sendo assumidos pelo Estado (LACAZ; PORTO; PINHEIRO, 2017).

O rompimento da Barragem de Rejeitos de Fundão, de propriedade da Samarco, empresa sob o controle acionário da Vale, em novembro de 2015 em Mariana/MG, acarretou danos morais, sanitários, ocupacionais, ambientais e psicossociais e deu visibilidade, também, à omissão das instituições nacionais, no que tange à responsabilização das empresas envolvidas. Este evento foi denominado pelo Ministério Público Federal como crime sócio-ocupacional-ambiental. No entanto, "[...] a notória morosidade da justiça no Brasil, dada a omissão das chamadas autoridades constituídas e a capacidade de procrastinação das grandes empresas, conforme seus interesses, mediante ações recursais de caráter jurídico-legais [...]" impossibilitam a apuração rigorosa das responsabilidades sobre o crime que cometeram (LACAZ; PORTO; PINHEIRO, 2017, p. 2).

O modelo de megamineração, que fez do Brasil o segundo maior exportador e da Vale a maior produtora mundial (300 milhões de toneladas de minério de ferro anualmente), é responsável pela devastação provocada a partir de Mariana. Como consequência, resíduos tóxicos se alastraram por 663 quilômetros até o Oceano Atlântico, gerando danos incalculáveis aos habitantes de 35 municípios em Minas Gerais e 4 municípios do Espírito Santo. Cerca de 1.430 hectares ficaram inutilizáveis para atividades agropecuárias devido à infertilidade provocada no solo (LACAZ; PORTO; PINHEIRO, 2017). Vários agricultores e pescadores, além dos indígenas Krenak (MG), Tupiniquim (ES) e Guarani (ES) sofreram privações (LACAZ; PORTO; PINHEIRO, 2017).

Acselrad (2000) provoca o debate em torno da associação que existe entre degradação ambiental e injustiça social, uma vez que há uma distribuição espacialmente desigual da poluição, segundo a raça/etnia das populações. A injustiça ambiental estaria relacionada, portanto, com a desigualdade na distribuição do que Porto-Gonçalves (2015) chama de proveitos e rejeitos, ou seja, dos benefícios e dos limites impostos pelas leis ambientais entre diferentes grupos ou classes sociais. 
De acordo com Wanderley, Mansur, Milanez e Pinto (2016), o crime da Vale em Mariana gerou cerca de 19 mortos e desaparecidos entre funcionários ligados à Samarco e moradores do Distrito de Bento Rodrigues, além de mais de 1.200 pessoas sem abrigo e, ainda, áreas de proteção permanente e unidades de conservação destruídas (WANDERLEY; MANSUR; MILANEZ; PINTO, 2016).

Esta situação sempre pode se agravar caso, para atrair os investimentos, sejam flexibilizadas as exigências socioambientais, permitido avanço sobre áreas protegidas, como vem ocorrendo na Argentina, Bolívia, Brasil e Uruguai (GUDYNAS, 2009). Esse movimento, que ocorre na América Latina, tem na Organização Mundial do Comércio um agente preponderante que, ao pressionar pela abertura das fronteiras, beneficia as grandes corporações transnacionais com as políticas de livre comércio e faz com que as políticas ambientais, nos países periféricos, se fragilizem ainda mais (GUDYNAS, 2009).

Há uma lógica na qual os rejeitos das corporações transnacionais permanecem no território, enquanto seus proveitos seguem para fora. Assim, a legislação ambiental é subsumida pela lógica comercial, para que haja livre circulação dos proveitos, mas não dos rejeitos (PORTO-GONÇALVES, 2015). A distribuição desigual entre rejeitos e proveitos faz parte da lógica da atuação do mercado na globalização neoliberal que, no caso da Vale, começa em 1997, como consequência do fenômeno global de venda de empresas públicas rentáveis para privatizar os lucros e socializar as perdas (TEITELBAUM, 2010).

Depois de levantar argumentos que atribuem o crime das empresas Samarco e Vale às pressões do mercado, Wanderley, Mansur, Milanez e Pinto (2016, p. 34) revelam como o Estado contribui para a ocorrência desses casos, tendo em vista que

as operações de disposição de rejeitos na indústria extrativa mineral no Brasil, em geral, e na Samarco, em particular, constituem uma opção política e tecnológica determinada por incentivos de mercado, práticas corporativas inadequadas e intensificadoras de riscos socioambientais e da inação estatal no que concerne à fiscalização e controle (WANDERLEY; MANSUR; MILANEZ; PINTO, 2016, p. 34).

Na SDR em análise, no que se refere à parceria entre mercado e Meio Ambiente, o artigo indefinido uma produz um efeito de sentido de cooperação. Tal cooperação tem por referente outro ator, que estaria implícito na relação mercado versus Meio Ambiente. Uma cooperação histórica entre Estado e capital pode ser evidenciada a partir do papel desempenhado pelo Estado brasileiro desde a privatização da então Companhia Vale do Rio Doce, em condições questionadas judicialmente, e, ainda, na proposta de legislação que favorece a mineração, indo até à omissão quanto às suas externalidades. Godeiro, Moura, Souza e Vieira (2007) consideram a desestatização da referida Companhia um negócio que beneficiou capitalistas brasileiros associados ao capital estrangeiro. Os autores afirmam que o governo brasileiro entregou uma empresa, consolidada e detentora das 
maiores reservas de minério de ferro então conhecidas no planeta, cujo valor de mercado foi multiplicado por dez uma década após sua venda.

Milanez e Santos (2013) ressaltam que, no Brasil, se dá um modelo de desenvolvimento neoextrativista, no qual o Estado provém financiamento, infraestrutura e regulação. É oportuno destacar que, segundo Gudynas (2009), apesar de não contribuir substancialmente para o desenvolvimento nacional, a mineração, típico setor extrativista, ainda é defendida pelos governos como motor de crescimento econômico. O protagonismo estatal promove o crescimento da mineração no Brasil, tornando-o uma potência da mineração de Natureza abundante, apesar dos baixos indicadores sociais e da falta de bem-estar (GUDYNAS, 2009).

A expansão da mineração é uma atividade econômica causadora de conflitos, não raras vezes, com o suporte de instituições governamentais (ROCHA; PORTO; PACHECO; LEROY, 2018). No Brasil, o licenciamento no setor de mineração se deu de forma a favorecer as empresas e dificultar a oposição popular, pois, tanto a licença para minerar quanto a licença ambiental não concedem poder de veto às populações afetadas (ARAUJO; FERNANDES, 2016). Os conflitos envolvendo a mineração na América Latina apontam a frequente cooperação entre o alto escalão do Estado e as empresas privadas estrangeiras e nacionais no que se refere à utilização dos recursos minerais (SCOTTO, 2013, p. 104).

Para Lacaz, Porto e Pinheiro (2017), na periferia do capitalismo, os estados são reais parceiros da mineração, pois as atividades de extração e beneficiamento no ramo da mineração e siderurgia, recordistas em consumo de energia e em capacidade poluidora. A legislação não se cumpre ou é flexibilizada em troca de favorecer investimentos em prevenção de riscos e melhoria das condições de trabalho a cargo das empresas. Licenciamentos se dão via audiências públicas não democráticas, órgãos ambientais oficiais não têm suporte financeiro e corpo técnico para atuar de maneira regular ou são pressionados à flexibilização por políticos e gestores empresariais, tendo em vista os ditos benefícios econômicos e políticos para o aumento do Produto Interno Bruto (PIB) e a geração dos royalties oriundos da atividade econômica (LACAZ, PORTO; PINHEIRO, 2017).

Para Gudynas (2009), as avaliações são débeis ou inadequadas, minimizam os impactos ambientais e a fiscalização se encontra fragilizada. Os impactos socioambientais não são mensurados economicamente, ficando excluídos das análises de custo-benefício. Outra evidência de parceria diz respeito ao financiamento do mercado às campanhas eleitorais de parlamentares nas três esferas de governo (LACAZ, PORTO; PINHEIRO, 2017). Interesses corporativos, destacadamente aqueles ligados ao agronegócio, mineração e obras de infraestrutura, influenciam o legislativo no Brasil, levando o Estado a aprovar leis que reforçam os interesses empresariais (ROCHA; PORTO; PACHECO; LEROY, 2018). 
Segundo o jornal O Estadão (LAGO; CARVALHO, 2019), a Vale e suas subsidiárias contribuíram com $\mathrm{R} \$ 82$ milhões no financiamento eleitoral de candidatos em 2014, concentrando as doações oficiais e legalizadas mais volumosas nos estados onde há mais operações: Minas (18\%), Pará (9\%) e Espírito Santo (8\%). Os candidatos que receberam valores da Vale foram maioria entre os eleitos.

Segundo Mello e Prates (2009), em um artigo publicado no Estado de Minas, a Vale também aumentou doações a candidaturas durante o debate do novo Código da Mineração, de relatoria do deputado federal, Leonardo Quintão, do PMDB (MG). Segundo informações analisadas por Turollo Júnior e Estarque (2019), publicadas na Folha de São Paulo, o referido deputado recebeu das mineradoras em 2014, o equivalente a $R \$ 2,1$ milhões ( $42 \%$ de sua arrecadação).

A Figura 1 expõe a proporção de deputados estaduais e federais eleitos com financiamento de campanha, que incluiu recursos da Vale, em 2014.

Figura 1 - Proporção de deputados eleitos com financiamento da Vale, 2014

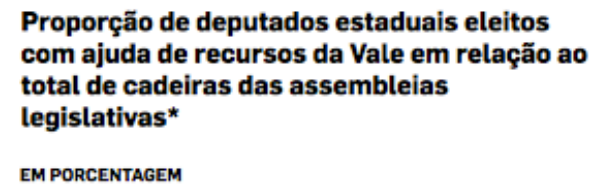

66,67

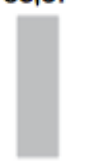

MS
PA

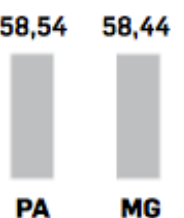

MG

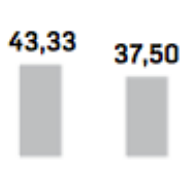

ES SE

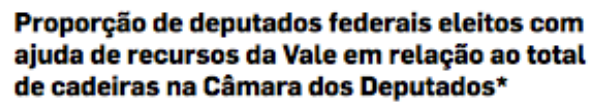

Proporção de deputados federais eleitos com ajuda de recursos da Vale em relação ao total

de cadeiras na Câmara dos Deputados *

EM PORCENTAGEM

80,00

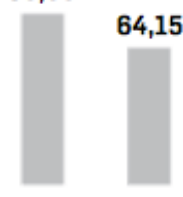

ES MG SE

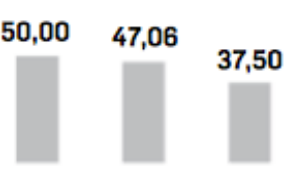

PA MS

Fonte: Lago; Carvalho (2019)

De acordo com a Folha, parlamentares que receberam doações de mineradoras propuseram mudanças em textos que acarretaram em retirada de fiscalização, pois ocupam cargos em comissões que influenciam o que é aprovado. Dos 52 parlamentares que, em 2014, compuseram a comissão para debater o novo Código da Mineração, 23 foram eleitos com apoio das mineradoras. Ainda segundo a Folha, após a devastação em Mariana, os únicos dois projetos para aprimoramento da Política Nacional de Segurança de Barragens que chegaram à Câmara ficaram paralisados na Comissão de Minas e Energia, na qual há mais de 30 parlamentares financiados pelo setor de mineração.

A Figura 2 apresenta os valores financiados por empresas de mineração, nas candidaturas de parlamentares em 2014, elaboradas a partir de dados do Tribunal Superior Eleitoral (TSE): 
Figura 2 - Financiamento das mineradoras para candidaturas em 2014

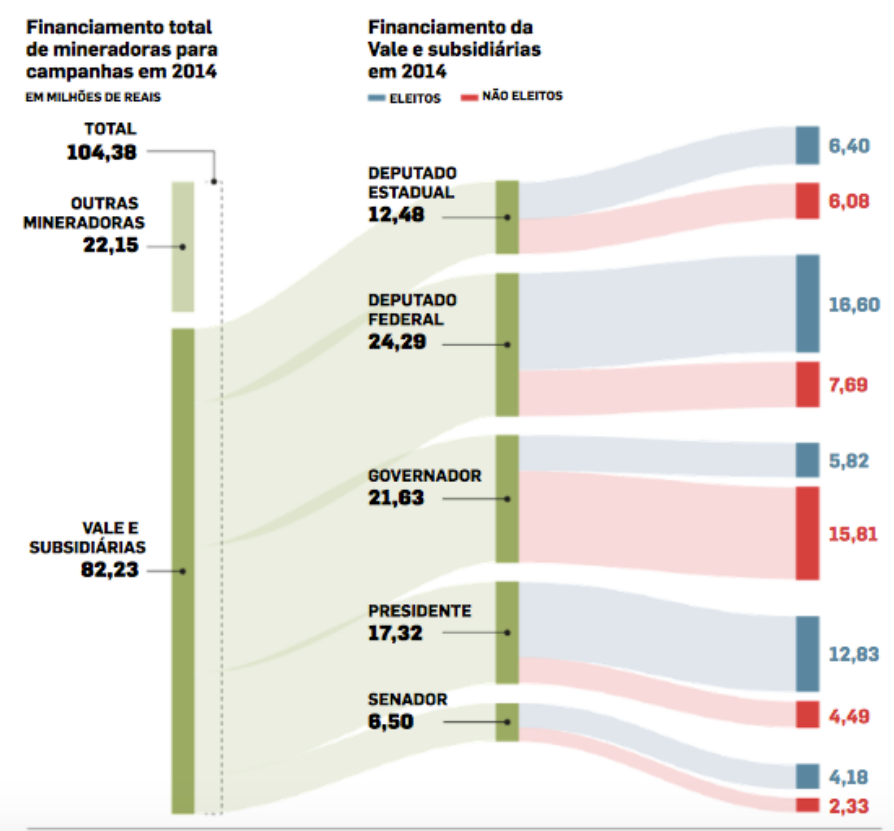

Fonte: Lago; Carvalho (2019)

A mineração é invasiva e ameaça a vida, sua expansão tem provocado tragédias e conflitos, mas também resistência no Brasil. Populações tradicionais têm seus territórios invadidos, povos ribeirinhos e os habitantes de diversos territórios urbanos e rurais, nos quais existe atividade de mineração, têm se envolvido em conflitos ambientais. Em diversos territórios, a população recusa a atividade econômica porque representa agressão ao modo ancestral de organizar a vida e de fazer uso do espaço (ARAUJO; FERNANDES, 2016; RENAK, 2019). No movimento de resistir, foi criada, em 2002, a Rede Brasileira de Justiça Ambiental, reunindo grupos acadêmicos e organizações de justiça ambiental, para fazer frente às demandas de movimentos sociais e populações afetadas (ROCHA; PORTO; PACHECO; LEROY, 2018).

A atuação internacional da Justiça nos Trilhos, que, desde 2007, une movimentos e associações e participou na fundação da Articulação Internacional dos Atingidos pela Vale, em 2010, também contribui para o movimento de resistência. Tal articulação possui representação dos países nos quais a Vale tem algum tipo de negócio e se autodenomina "uma rede de movimentos sociais, organizações e centrais sindicais de diversos países, incluindo populações, comunidades e trabalhadores atingidos negativamente nas suas formas de vida e nos seus direitos pela forma de atuação da Vale" (ARTICULAÇÃO INTERNACIONAL DE ATINGIDOS PELA VALE, 2012). Além de 
Justiça nos Trilhos, há, ainda, o Movimento pela Soberania Popular na Mineração, iniciado em 2012, para combater o Projeto Grande Carajás ${ }^{11}$ da Vale (LACAZ, PORTO; PINHEIRO, 2017).

Em fevereiro de 2019, O Movimento dos Atingidos por Barragens (MAB) lançou nacionalmente um dossiê intitulado A privatização mata: análise do MAB sobre o crime da Vale em Brumadinho/MG, com o objetivo de denunciar o crime da Vale a partir da visão dos trabalhadores (MOVIMENTO DOS ATINGIDOS POR BARRAGENS, 2019). No referido documento, o Movimento denuncia e cobra das autoridades a responsabilização da empresa pela devastação causada pela lama tóxica que provocou mortes, deixou muitas pessoas com problemas de saúde e dizimou o Rio Paraopeba, afluente do São Francisco, em 25 de janeiro de 2019.

Quanto ao crime da Vale em Brumadinho (MG), o artigo veiculado no G1 Minas contabilizou, até 19/05/2019, 241 mortes, 29 desaparecimentos e 395 sobreviventes localizados. Um relatório da Fundação SOS Mata Atlântica denuncia as 14 mil toneladas de rejeito contaminando o rio, tornando suas águas impróprias e indisponíveis por 305 quilômetros. Foram identificados metais pesados na água, como: manganês, cobre e cromo, em níveis acima dos limites máximos regulamentados. Segundo o relatório, 112 hectares de florestas nativas foram devastados, sendo 55 hectares de áreas bastante preservadas (RIBEIRO, 2019).

Tanto o documento do MAB quanto o relatório da SOS Mata Atlântica são explícitos em revelar a injustiça ambiental e o sentimento de impunidade contra as violações cometidas pela Vale:

\begin{abstract}
a sensação de impunidade e de injustiça que paira sobre o país, desde a tragédia da Samarco, Vale e BHP na bacia do rio Doce, agravada com esse imensurável dano socioambiental, colocam em xeque a capacidade das instituições brasileiras de adotar medidas eficazes de monitoramento sistemático, controle e uso de tecnologias mais modernas, capazes de evitar que tragédias anunciadas como essas se repitam no Brasil (RIBEIRO, 2019, p. 41).

A impunidade e conivência do judiciário com as empresas é a autorização para que novos crimes aconteçam. Em Mariana, por exemplo, as multas e processos contra a Vale e de indenizações aos atingidos foram suspensas por iniciativa do próprio judiciário, que atua mais como advogado da Vale do que defensor da justiça (MOVIMENTO DOS ATINGIDOS POR BARRAGENS, 2019, p. 18).
\end{abstract}

As transcrições acima, extraídas do MAB e da SOS Mata Atlântica, oferecem elementos para caracterizar, ainda mais, a parceria posta na Sequência Discursiva em análise, uma vez que há uma parceria entre Estado e capital que, sob um argumento técnico-científico supostamente neutro, na prática, justificam os empreendimentos em detrimento de outras análises que os colocariam em questão (ROCHA; PORTO; PACHECO; LEROY, 2018, p. 715).

\footnotetext{
${ }^{11}$ Iniciado durante o governo do presidente João Batista Figueiredo, para exploração dos recursos minerais da Serra dos Carajás, ocupa quase um milhão de quilômetros quadrados na região amazônica, entre os estados do Pará e Maranhão. Houve a implantação de gigantesca infraestrutura: hidrelétrica de Tucuruí, estrada de ferro Carajás e porto de Ponta da Madeira, em São Luís.
} 
Os excertos do MAB e do SOS Mata Atlântica, pela via do interdiscurso, permitem constatar uma dimensão perversa da parceria presente na Sequência. Rocha, Porto, Pacheco e Leroy (2018) afirmam como é comum o Estado brasileiro utilizar o argumento jurídico-científico para subsidiar e justificar decisões que favoreçam o projeto econômico, desconsiderando o Meio Ambiente e os direitos humanos e sociais das populações atingidas durante o licenciamento ambiental ou já em caso de litígio.

\section{Considerações finais}

O cotejamento do referencial teórico, com dados recentes disponíveis na imprensa e com a Sequência Discursiva analisada, demonstrou uma relação entre instâncias do Estado brasileiro e o mercado da mineração, o que gera uma distribuição desigual entre rejeitos e proveitos, levando à externalização dos danos sociais e ambientais da atividade produtiva.

No modelo socioambiental vigente, as grandes corporações, como é o caso da Vale, realizam uma apropriação privada dos bens naturais coletivos, pois necessitam aumentar sua produtividade e alcançam esse fim ao transformar bens não mercantis em mercadoria, ao mesmo tempo em que transferem os danos socioambientais à sociedade. No dizer de Gudynas (2009), desse modo se dá a externalização dos danos sociais e ambientais.

A Vale, cujos rejeitos ficam em território nacional enquanto os lucros são desnacionalizados, pratica a injustiça ambiental (ACSELRAD, 2000), como se pôde constatar nas consequências dos dois recentes crimes, dos quais a empresa foi protagonista, atingindo as comunidades tradicionais, povos indígenas, trabalhadores e moradores que vivem ao longo dos rios Doce e Paraopeba. Destarte, a parceria entre o Estado e o mercado, de um lado, favorece ainda mais o poder econômico da empresa, que fica com os proveitos enquanto, de outro, prejudica a Natureza e as pessoas atingidas direta e indiretamente pelos rejeitos dos empreendimentos.

A mercadificação da natureza, a corporativização e privatização de bens e utilidades públicas, utilizando-se do poder do Estado, é o que vem sendo o cerne da atividade da mineração no Brasil, especialmente como foi demonstrado aqui pela ação da Vale, caracterizando o fenômeno da acumulação por espoliação (HARVEY, 2013).

Evidenciou-se um descolamento entre a noção de um modelo socioambiental que se anuncia como aquele capaz de permitir o crescimento econômico sem comprometer a Natureza, a ponto de prejudicar as condições de as futuras gerações desfrutarem do planeta. Na prática, o exemplo da mineração revelou-se um modelo extrativista que desconsidera o ideal do desenvolvimento sustentável na prática, embora o endosse discursivamente.

Por um lado, o mercado, em nome da busca de lucro incessante, negligencia a capacidade de a Natureza suportar os impactos da atividade produtiva altamente impactante, como é o caso da 
mineração. Por outro, instâncias do Estado brasileiro agem de forma a assegurar que a mineração obtenha financiamento, infraestrutura e regulação favorável. Soma-se a isso o financiamento de legislaturas, cujos parlamentares eleitos atuam de forma a beneficiar os interesses privados da mineração em detrimento do interesse público. Ademais, o papel desempenhado pelo Judiciário brasileiro vem sendo questionado, no que tange à não aplicação ou atenuação de multas, morosidade em processos e omissões.

O modelo socioambiental vigente, desde o início da década de 1990, revelou-se mais funcional ao desenvolvimento do capitalismo do que à manutenção das condições de vida no planeta. A perspectiva da sustentabilidade deve ser questionada não pela sua apropriação e utilização prómercado, pois esta é sua finalidade em si. Faz-se necessário provocar a reflexão sobre a incapacidade do modelo socioambiental vigente em preservar as condições de existência da Natureza e da humanidade como parte dela. Esse modelo não apresenta o real compromisso com as fontes dos recursos naturais, com os trabalhadores e tampouco com as populações que vivem no entorno da atividade produtiva. É o momento de entender que o limite do modelo socioambiental vigente se defronta, ainda hoje, com a mesma contradição que outrora lhe deu origem: as necessidades de reprodução da acumulação, nos moldes capitalistas, são incompatíveis com as necessidades de preservação das condições da vida.

\section{Referências}

ACSELRAD, Henri. Justiça Ambiental: novas articulações entre meio ambiente e democracia. In: IBASE/CUTRJ/IPPUR-UFRJ. Movimento Sindical e Defesa do Meio Ambiente: o debate internacional. Rio de Janeiro: IPUR, 2000. p.7-12. (Série Sindicalismo e Justiça Ambiental, v.3).

ADÃO, Sonia Maria. Os discursos confrontados no processo de privatização: o caso companhia Vale do Rio Doce. Orientador: Helena Hathsue Nagamine Brandão, 2006. 211f. Tese (Doutorado em Filologia e Língua Portuguesa) - Faculdade de Filosofia, Letras e Ciências Humanas, Universidade de São Paulo, São Paulo, 2006. Disponível em: http://www.teses.usp.br/teses/disponiveis/8/8142/tde01022008-105831/. Acesso em: 23 ago. 2016.

AMARAL, Maria Virgínia Borges. O avesso do discurso: análise de práticas discursivas no campo do trabalho. Maceió: EDUFAL, 2007.

ARAÚJO, Eliane R.; FERNANDES, Francisco R. Chaves (2016) Mineração no Brasil: crescimento econômico e conflitos ambientais. In: GUIMARÃES, Paulo Eduardo; PÉREZ CEBADA, Juan Diego (Eds). Conflitos Ambientais na Indústria Mineira e Metalúrgica: o passado e o presente. Rio de Janeiro: CETEM/CICP, 2016. cap. 2, p. 65-88.

ARTICULAÇÃO INTERNACIONAL DE ATINGIDOS PELA VALE. Relatório de Insustentabilidade da Vale. [s.l.: AIAAV], 2012. Disponível em: https://atingidospelavale.wordpress.com/. Acesso em: 15 ago. 2016

BANERJEE, Subhabrata Bobby. Who Sustains Whose Development? Sustainable Development and 
the Reinvention of Nature. Organization Studies, London, v. 24, n. 1, p. 143-180, jan. 2003.

BIERMANN, Frank; KANIE, Norichika; KIM, Rakhyun E. Global governance by goal-setting: the novel approach of the UN Sustainable Development Goals. Current Opinion in Environmental

Sustainability, v. 26-27, p. 26-31, jun. 2017. Disponivel em:

https://www.sciencedirect.com/science/article/pii/S1877343517300209. Acesso em: 15 jun. 2018.

CAPOBIANCO, João Paulo. O que podemos esperar da Rio-92?. São Paulo em Perspectiva, São Paulo, v. 6, n. 1-2, p. 13-17, jan/jun. 1992. Disponível em:

http://produtos.seade.gov.br/produtos/spp/v06no1-02/v06no1-02_03.pdf. Acesso em 22 nov. 2018.

COMISSÃO MUNDIAL SOBRE MEIO AMBIENTE E DESENVOLVIMENTO - CMMAD. Nosso futuro comum. 2. ed. Rio de Janeiro, RJ: Ed. da FGV, 1991. 430p.

COURTINE, Jean-François. Análise do discurso político: o discurso comunista endereçado aos cristãos. São Carlos, SP: EdUFSCar, 2014. 250p. ISBN 978-85-7600-160-7.

COURTINE, Jean-Jacques. Definição de orientações teóricas e construção de procedimentos em Análise do Discurso. Policromias-Revista de Estudos do Discurso, Imagem e Som, v. 1, n. 1, 2016.

DALLA COSTA, Armando. La Vale dans Le nouveau contexte d'internationalization des entreprises brésiliennes. Revista Entreprises et Histoire, Paris, n. 54, p. 86-106, avril 2009. ISSN 1161-2770.

DIAS, Reinaldo. Gestão ambiental: responsabilidade social e sustentabilidade. 2. ed. São Paulo: Atlas, 2012. ISBN: 978-85-224-6753-2.

ESCOBAR, Arturo. La invención del Tercer Mundo: construcción y deconstrucción del desarrollo. Caracas, Venezuela: Fundación Editorial el perro y la rana. 2007, p. 64 (Serie colonialidad/modernidad/descolonialidad). ISBN 978-980-396-776-5

FARIA, José Henrique de. Por uma teoria crítica da sustentabilidade. Organizações e Sustentabilidade, Londrina, v. 2, n. 1, p. 2-25, 2014.

FOLADORI, Guillermo; TOMMASINO, Humberto. El concepto de desarrollo sustentable treinta años después. Desenvolvimento e Meio Ambiente, Curitiba, n. 1, p. 41-56, jan./jun. 2000. ISSN: 21769109 versão online. DOI: http://dx.doi.org/10.5380/dma.v1io.3056. Disponível em: https://revistas.ufpr.br/made/article/view/3056. Acesso em: 27 nov. 2018.

FOLHA DE SÃO PAULO. Vale perde mais de R $\$ 70$ bilhões em valor de mercado após tragédia em Brumadinho. Folha de São Paulo, São Paulo, jul. 2019a. Disponível em: https://www1.folha.vol.com.br/mercado/2019/01/acoes-da-vale-despencam-apos-tragedia-embrumadinho.shtml. Acesso em 29 jul. 2019.

FOLHA DE SÃO PAULO. Seis meses após Brumadinho, Vale ainda está 10\% abaixo de seu valor de mercado. Folha de São Paulo, São Paulo, jul. 2019b. Disponível em:

https://www1.folha.vol.com.br/mercado/2019/07/seis-meses-apos-brumadinho-vale-esta-proximade-recuperar-seu-valor-de-mercado.shtml?loggedpaywall. Acesso em 29 jul. 2019.

FREITAS, Rosana de Carvalho Martinelli; NELSIS, Camila Magalhães; NUNES, Letícia Soares. A crítica marxista ao desenvolvimento (in) sustentável. Revista Katálysis, Florianópolis, v. 15, n. 1, p. 41-51, jan./jun. 2012. ISSN 1982-0259 versão online. DOI: http://dx.doi.org/10.159o/S1414- 
49802012000100004. Disponível em: http://www.scielo.br/scielo.php?script=sci_arttext\&pid=S1414498020120001000000\&lng=en\&nrm=iso. Acesso em: 01 set. 2019.

FROGER, Géraldine. Significations et ambiguïtés de la gouvernance dans le champ du développement durable. Mondes en développement, Paris, v. 136, n. 4, p. 11-28, febr. 2006.

G1 MINAS. Sobe para 241 as mortes confirmadas em Brumadinho: De acordo com a Defesa Civil, 29 pessoas continuam desaparecidas. G1 Minas Gerais, Belo Horizonte, 19 maio. 2019. Disponível em: https://g1.globo.com/mg/minas-gerais/noticia/2019/05/19/sobe-para-241-as-mortes-confirmadasem-brumadinho.ghtml. Acesso em: 18 jul. 2019.

GAMEIRO, Mariana Bombo Perozzi; MARTINS, Rodrigo Constante. Da mercantilização da natureza à criação de mercadorias verdes. REDD - Revista Espaço de Diálogo e Desconexão, Araraquara, v. 8, n. $1 / 2,2014$.

GODEIRO, Nazareno; MOURA, Efraim; SOUZA, Paulo Soares de; VIEIRA, Valério. Vale do Rio

Doce: nem tudo que reluz é ouro, da privatização à luta pela reestatização. São Paulo: Sundermann, 2007. 16op., ISBN 978-85-99156-20-9.

GODOY, Arilda Schmidt. Introdução à pesquisa qualitativa e suas possibilidades. Revista de Administração de Empresas - RAE, São Paulo, v.35, n.2, p.57-63, mar./abr. 1995.

GUDYNAS, Eduardo. Diez tesis urgentes sobre el nuevo extractivismo. In: CENTRO ANDINO DE ACCIÓN POPULAR; CENTRO LATINO AMERICANO DE ECOLOGÍA SOCIAL. Extractivismo, política y sociedade. Quito: CAAP; CLAES, 2009. p.187-225. ISBN 789978510247.

HARVEY, David. A acumulação via espoliação. HARVEY, David. O Novo Imperialismo. Tradução Adail Sobral e Maria Stela Gonçalves. 7. ed. São Paulo: Edições Loyola, 2013. Cap. 4, P. 115-1498. ISBN: 978-85-15-02971-6.

HARVEY, David. A Geografia da acumulação capitalista: uma reconstrução da teoria Marxista. In: HARVEY, David. A produção capitalista do espaço. 2. ed. Tradução Carlos Szlak. São Paulo: Annablume, 2006. Cap. 2, p. 32-72. (Coleção Geografia e Adjacências). ISBN: 85-7419-496-4.

ICHIKAWA, Elisa Yoshie; CARRIERI, Alexandre de Pádua. Da Rio 92 à Rio+ 20: a revista Exame e a institucionalização da sustentabilidade Rio 92 to Rio+ 20: the magazine Exame and the institutionalization of sustainability. Razón y Palabra: Primera Revista Electrónica en Iberoamérica Especializada en Comunicación, v. 18, n. 87, p. 417-433, jul./sept. 2014. ISSN: 605-4806.

IVO, Anete Brito Leal. A noção de governança: um novo regime de ação para o desenvolvimento sustentável e a produção das ciências sociais. In: IVO, Anete Brito Leal (Org.). A reinvenção do desenvolvimento: agências multilaterais e produção sociológica. Salvador: Edufba, 2016. Cap. 2, p. 37-104. ISBN: 978-85-232-1545-3.

KRENAK, Ailton. Ideias para adiar o fim do mundo. São Paulo: Companhia das Letras, 2019.

LACAZ, Francisco Antônio de Castro; PORTO, Marcelo Firpo de Sousa; PINHEIRO, Tarcísio Márcio Magalhães. Tragédias brasileiras contemporâneas: o caso do rompimento da barragem de rejeitos de Fundão/Samarco. Revista Brasileira de Saúde Ocupacional, São Paulo, v. 42, eg, Epub, 26 jul. 2017. ISSN 0303-7657 versão online. DOI: http://dx.doi.org/10.1590/2317-6369000016016. Disponível em: http://www.scielo.br/scielo.php?script=sci_arttext\&pid=S0303-

76572017000100302\&lng=en\&nrm=iso. Acesso em: 19 ago. 2019. 
LAGO, Cecília do; CARVALHO, Marco Antônio. Com R\$ 82 milhões em doações eleitorais, Vale espalhou influência em 25 Estados e no Congresso. Estadão, São Paulo, 01 fev. 2019. Disponível em: https://brasil.estadao.com.br/noticias/geral,com-r-82-milhoes-em-doacoes-eleitorais-valeespalhou-influencia-em-25-estados-e-no-congresso,70002702885. Acesso em: 23 abr. 2019.

LANDRUM, Nancy E. Stages of corporate sustainability: integrating the strong sustainability worldview. Organization \& Environment, Thousand Oaks, v. 31, n. 4, p. 287-313, jul, 2017.

LAUTIER, Bruno. O consenso sobre as políticas sociais na América Latina, negação da democracia?. Caderno CRH, Salvador, v. 23, n. 59, p. 353-368, ago. 2010.

LAYRARGUES, Philippe Pomier. Do ecodesenvolvimento ao desenvolvimento sustentável: evolução de um conceito?. Proposta: Revista Trimestral de Debate da Fase, Rio de Janeiro, ano 25, n. 71, p. 15, dez. 2016 / fev. 1997.

LEFF, Enrique. Ecologia, capital e cultura: a territorialização da racionalidade ambiental. Tradução: Jorge E. Silva; Revisão Técnica: Carlos Walter Porto-Gonçalves. Petrópolis, RJ: Vozes, 2009. 439p., (Coleção Educação Ambiental). ISBN 978-85-326-3918-9.

LÉLÉ, SHARACHCHANDRA M. Sustainable development: a critical review. World Development, Amsterdã, v.19, n. 6, p. 607-621, 1991. ISSN: 0305-750X.

LIMA, Gabriela Garcia Batista. O conceito de governança global do desenvolvimento sustentável no estudo da efetividade da norma jurídica: reflexões epistemológicas. Nomos: Revista do Programa de Pós-graduação em Direito da UFC, Fortaleza, v. 32 n. 2, jul./dez. 2012. ISSN 1807-3840. Disponível em: http://periodicos.ufc.br/nomos/article/view/356. Acesso em: 22 nov. 2018.

LOPES, Carlos. Cooperação e desenvolvimento humano: a agenda emergente para o novo milênio. São Paulo: UNESP, 2005.

MALDIDIER, Denise. Elementos para uma história da análise do discurso na França. In: ORLANDI, Eni Puccinelli (org.). Gestos de leitura: da história no discurso. 4. ed. Campinas: Unicamp, 2014. p. 17-30.

MILANEZ, Bruno; SANTOS, Rodrigo Salles Pereira dos. Neoextrativismo no Brasil?: Atualizando a análise da proposta do novo marco legal da mineração. Revista Pós Ciências Sociais, São Luís, v.10, n.19, jan/jun. 2013.

MONTIEL, Ivan; DELGADO-CEBALLOS, Javier. Defining and Measuring Corporate Sustainability: Are We There Yet?. Organization \& Environment, Thousand Oaks, v. 27, n. 2, p. 113-139, 2014. DOI: https://doi.org/10.1177/1086026614526413. Disponível em:

https://journals.sagepub.com/doi/abs/10.1177/1086026614526413?journalCode=oaec Acesso em:

MORAES, Reginaldo Carmello Correa de. Estado, desenvolvimento e globalização. São Paulo: Unesp, 2006. 192p. ISBN: 85-7139-726-o

MOREIRA, Luciano Accioly Lemos. A (In)sustentabilidade do discurso do desenvolvimento sustentável. Orientadora: Maria do Socorro Aguiar Oliveira Cavalcante. 2010. 163 f. Tese (Doutorado em Letras: Linguística) - Programa de Pós-Graduação em Letras e Linguística, Faculdade de Letras, Universidade Federal de Alagoas. Maceió, 2010. 
MOVIMENTO DOS ATINGIDOS POR BARRGENS. O lucro vale a vida: análise do MAB sobre o crime da Vale em Brumadinho/MG. REVISTA MAB, São Paulo, p. 28, fev. 2019.

NOBRE Marcos; AMAZONAS, Maurício de Carvalho. (Org.). Desenvolvimento sustentável: a institucionalização de um conceito. Brasília: Edições IBAMA, 2002

OLIVEIRA, José Antônio Puppim de. Empresas na Sociedade: sustentabilidade e responsabilidade social. Rio de Janeiro: Elsevier, 2008.

OREIRO, José Luís; FEIJO, Carmem A. Desindustrialização: conceituação, causas, efeitos e o caso brasileiro. Revista de Economia Politica, São Paulo, v. 30, n. 2, p. 219-232, abr./jun. 2010. ISSN 0101-3157. DOI: http://dx.doi.org/10.1590/S0101-31572010000200003. Disponível em: $<$ http://www.scielo.br/scielo.php?script=sci_arttext\&pid=S0101-

31572010000200003\&lng=pt\&nrm=iso >. Acesso em: 29 mar. 2019.

ORLANDI, Eni Puccinelli. Discurso em análise: sujeito, sentido e ideologia. 3. ed. Campinas: Pontes Editores, 2016. ISBN 978-85-7113-382-2.

ORLANDI, Eni Puccinelli. Observações sobre análise de discurso. In: ORLANDI, Eni Puccinelli (Org.). Terra à vista!: discurso do confronto: velho e novo mundo. São Paulo: Cortez, 199o. p. 25-37. ISBN: 978-85-249-0275-8.

ORLANDI, Eni Puccinelli. Vão surgindo sentidos. In: ORLANDI, Eni Puccinelli. (Org.). Discurso fundador: a formação do país e a construção da identidade nacional. São Paulo: Pontes, 1993a. Cap. 1, p. 11-25. (Coleção Linguagem/crítica). ISBN 85-7113-078-7.

ORLANDI, Eni Puccinelli. Prefácio. In: ORLANDI, Eni Puccinelli (Org.). Discurso fundador: a formação do país e a construção da identidade nacional. São Paulo: Pontes, 1993b. p. 7-9. (Coleção Linguagem/crítica). ISBN 85-7113-078-7.

PATTBERG, Philipp. La gouvernance, une simple mode?. In: JACQUET, Pierre; PACHAURI, Rajendra K.; TUBIANA, Laurence (dir.). Regards sur la terre: L'annuel du développement durable. Paris: Les Presses Sciences Po., 2009. [Un système à l'épreuve du développement durable. Chapitre 1, p. 8395]. ISBN 978-2-7246-1091-8.

PATTI, Ane Ribeiro; SOUSA, Lucília Maria Abrahão e; GARCIA, Dantielli Assumpção. Pelos entremeios da análise do discurso: nos fios de Michel Pêcheux. Rev. psicol. polít., São Paulo, v. 17, n. 39, p. 220-231, ago. 2017. Disponível em $<$ http://pepsic.bvsalud.org/scielo.php?script=sci_arttext\&pid=S1519549X2017000200003\&lng=pt\&nrm=iso>. Acesso em 27 ago. 2019.

PÊCHEUX, Michel. Semântica e discurso: uma critica a afirmação do obvio. 5. ed. reimpr. Campinas, SP: Editora da Unicamp, 2016.

PEZZOLI, Keith. Sustainable Development: a transdisciplinary overview of the literature. Journal of Environmental Planning and Management, Abingdon, v. 40, n. 5, p. 549-574, sept. 1997.

PHILLIPS, Nelson. HARDY, Cynthia. Discourse analysis investigating processes of social construction. Thousand Oaks California: SAGE Publications Inc., 2002.

PORTO-GONÇALVES, Carlos Walter. A globalização da natureza e a natureza da globalização. 6 . ed. Rio de Janeiro: Civilização Brasileira, 2015. 
PRATES, Vinicius. A natureza deslocada: construção dos sentidos da sustentabilidade nas revistas de economia e negócios Exame, Época Negócios e IstoÉ Dinheiro. Orientador: José Luiz Aidar Prado. 2013. 220 f. Tese (Doutorado em Comunicação) - Pontifícia Universidade Católica de São Paulo, São Paulo, 2013.

RIBEIRO, Malu (Coord.). Laudo Técnico Parcial: expedição bacia do rio doce. São Caetano do Sul: Fundação SOS Mata Atlântica. Programa Rede das Águas. Universidade Municipal de São Caetano do Sul-USCS, 2019. [Projeto Observando os Rios]

RIST, Gilbert. El desarrollo: historia de una creencia occidental. Madri: Los Libros de la. Catarata, 2002.

ROCHA, Diogo Ferreira da; PORTO, Marcelo Firpo; PACHECO, Tania; LEROY, Jean Pierre. The map of conflicts related to environmental injustice and health in Brazil. Sustainability Science, Helsinki, v. 13, n. 3, p. 709-719, may. 2018.

RUHIL, Rohini. Millennium development goals to sustainable development goals: challenges in the health sector. International Studies, Thousand Oaks, v. 52, n. 1-4, 118-135, dec. 2017.

RUSSO, Fátima Ferreira. Privatização da Vale do Rio Doce: Valores, Manifestação e Implicações. Orientador: Valderez Ferreira Fraga. 2002. 86f. Dissertação (Mestrado em Administração) Fundação Getúlio Vargas, Rio de Janeiro, 2002.

SANTOS FILHO, Onofre. O fogo de prometeu nas mãos de Midas: desenvolvimento e mudança social. In: CAMPOS, Taiane Las Casas (Org.). Desenvolvimento, desigualdades e relações internacionais. Belo Horizonte: Ed. PUC Minas, 2005.

SANTOS, Theotônio dos. Introducción; La corporación multinacional: célula del imperialismo contemporáneo. In: SANTOS, Theotônio dos. Imperialismo y dependencia. Caracas: Fundación Biblioteca Ayacucho. 2011. Cap. 1 e 2, p. 7-119. ISBN 978-980-276-490-7.

SCOTTO, Gabriela. Estados nacionais, conflitos ambientais e mineração na América Latina. Letras Verdes. Revista Latinoamericana de Estudios Socioambientales, Quito, n. 14, p. 95-116, sept. 2013. Disponível em: https://repositorio.flacsoandes.edu.ec/xmlui/handle/10469/5972. Acesso em: 10 ago. 2019.

SZÉKELY, Francisco; KNIRSCH, Marianna. Responsible leadership and corporate social responsibility: metrics for sustainable performance. European Management Journal, London, v. 23, n. 6, p. $628-647$, dec. 2005.

TEITELBAUM, Alejandro. La armadura del capitalismo: El poder de las sociedades transnacionales en el mundo contemporáneo, España: Editorial Icaria, 2010. (Colección : Antrazyt; v. 318). ISBN: 978$84-9888-144-8$.

TETREAULT, Darcy. La megaminería en México. Reformas estructurales y resistencia. Letras Verdes. Revista Latinoamericana de Estudios Socioambientales, Quito, n. 14, p. 214-232, sept. 2013.

TRUMAN, Harry S. Truman's inaugural address, january 20, 1949. Washington, DC: Library and Museum, 1949. Disponível em: https://www.trumanlibrary.org/whistlestop/50yr_archive/inagural20jan1949.htm. Acesso em: 04 mar. 2016. 
TUROLLO JÚNIOR, Reynaldo; ESTAROUE, Marina. Bancada da lama barra ações para melhorar segurança em barragens: Deputados receberam doações de empresas, mas negam defender o setor. Folha de São Paulo, São Paulo, 4 fev. 2019. Disponível em:

https://www1.folha.vol.com.br/cotidiano/2019/02/bancada-da-lama-barra-acoes-para-melhorarseguranca-em-barragens.shtml. Acesso em: 23 abr. 2019.

VALE. Demonstrações financeiras (2008-2017). Rio de Janeiro: Vale, c2017.

VALE. Relatório de Sustentabilidade 2011. Rio de Janeiro, 2011.

VEIGA, José Eli da. Para entender o desenvolvimento sustentável. São Paulo: Editora 34, 2015. 232p. ISBN: 978-85-7326-612-2.

VISVANATHAN, Shiv. Mrs. Bruntland's Disenchanted Cosmos. Alternatives: Global, Local, Political, Amsterdam, v. 16, n. 3, p. 377-384, jul./set. 1991.

VITALE, Denise; SANTOS NETO, Mario Joaquim dos. Da agenda da ONU à produçãodas Ciências Sociais no Brasil: reflexões sobre desenvolvimento sustentável e povos indígenas. In: IVO, Anete Brito Leal (Org.). A reinvenção do desenvolvimento: agências multilaterais e produção sociológica. Salvador: Edufba, 2016. Cap. 3, p. 105-150. ISBN: 978-85-232-1545-3.

WANDERLEY, Luiz Jardim; MANSUR, Maíra Sertã; MILANEZ, Bruno; PINTO, Raquel Giffoni. Desastre da Samarco / Vale / BHP no Vale do Rio Doce: aspectos econômicos, políticos e socioambientais. Ciência e Cultura. São Paulo, v. 68, n. 3, p. 30-35, jul./set. 2016. ISSN 2317-6660 versão online. DOI: http://dx.doi.org/10.2180o/2317-66602016000300011. Disponível em: http://cienciaecultura.bvs.br/scielo.php?script=sci_arttext\&pid=Sooog-

67252016000300011\&lng=en\&nrm=iso. Acesso em: 22 nov. 2018.

YIN, Robert K. Pesquisa Qualitativa: do início ao fim. Porto Alegre: Artmed, 2016.

\section{Detalhes dos autores}

Paulo Everton M. Simões

Doutor em Administração, professor pesquisador da Universidade Federal de Alagoas. E-mail: paulo.simoes@arapiraca.ufal.br.

Sóstenes Ericson

Doutor em Linguística, professor pesquisador da Universidade Federal de Alagoas. E-mail: sericsonı@hotmail.com. 